\title{
FUNCTION OF PEDIGREE STRAINS OF PASTURE PLANTS
}

By L. CORKILL, Grasslands Division, Department of Scientific \& Industrial Research, Palmerston North.

As an introduction to this general discussion on the performance of pasture plants in different regions I propose to point out what pedigree strains are supposed to do. Those who follow me will show what they actually do. It remains to be seen what correlation there is between our stories. What these plants are supposed to do and what they actually do will depend very largely on the management they are given, so the function and performance of bred strains must necessarily be considered in relation to pasture management.

Their function can be stated quite simply: to provide the maximum quantity of high-quality herbage at the time it is required and at the lowest cost per 'unit.

Pasture production does not usually coincide with animal requirements. It is usually too low in late winter-early spring period and late summer and too high in spring and early summer. The relative extent of shortage and surplus, however, varies with the class of stock. The requirements of the ewe and fat lamb, for instance, are normally more nearly met than those of the milking cow.

In practice the farmer overcomes periods of deficiency and excess by making hay and silage, saving pasture in situ, and growing supplementary crops. The range of pedigree plants available, with their different seasonal productions., should assist in reducing the extent of such practices.

The Grasslands Division's plant breeding work was first devoted to the development of those grasses and clovers which were already . certified following Levy's and Davies' work on strain identification and selection. Strains with improved productivity, disease resistance, leafiness, and persistency were bred, increased, and distributed under the seed certification scheme.. The superiority of these' strains over those from which they were produced has been discussed 
in papers read to the 1949 conference of this Association and -elsewhere, so it is not proposed to consider this aspect further here.

The next stage in the breeding programme was the production of $\mathrm{H} 1$, or as it now known, shortrotation ryegrass from crosses of perennial and Italian. It has the winter production of Italian ryegrass, but higher annual production and greater persistency. To the list of pedigree pasture plants was thus added one with high winter yield and the potentiality to spread the seasonal production of both temporary and permanent pastures.

Before discussing the use of these pedigree strains to extend production, it is proposed to consider their seasonal growth characteristics and reaction to grazing management.

Comparisons of species in respect to seasonal production in mixtures are beset with difficulties. Performance is influenced so much by fertility, temperature, moisture, and grazing management. However, the following diagram based on figures from trials carried out at Palmerston North in 1946-48 does indicate the important differences in seasonal production between perennial ryegrass, short-rotation ryegrass, cocksfoot, timothy, and white clover. Each grass was sown in a mixture with white clover and the pastures were frequently rotationally grazed. The production from both grass and clover is shown in pounds of dry matter per acre on a seasonal basis with spring taken as, September to November.

\section{SEASONAL PRODUCTION of GRASSES with. WHITE CLOVER}

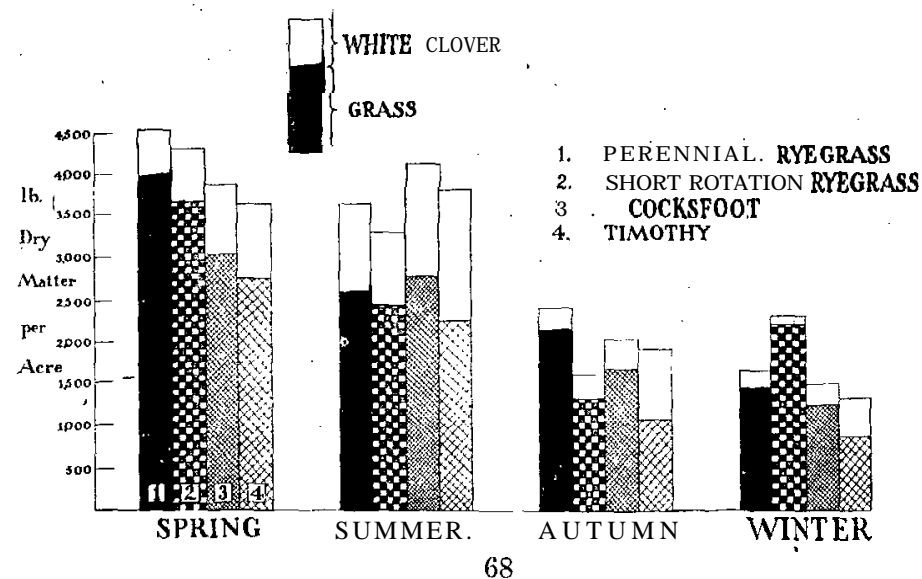


In annual herbage production (grass + clover) there is not a great difference between the four grassclover mixtures. Perennial ryegrass-white clover gave the highest production of $12,200 \mathrm{lb}$. and timothy-white clover the lowest of $10,600 \mathrm{lb}$. In the production from , grass alone there is a much greater range. The yields are : perennial ryegrass, $10,100 \mathrm{lb}$., short-rotation ryegrass, 9;600lb., cocksfoot, $8,700 \mathrm{lb}$., and timothy, 6,800 lb. The' annual production from white clover is roughly inversely related to the vigour of the associated grass. The clover growth in association with perennial ryegrass, short-rotation ryegrass, cocksfoot, and timothy is $2100,1900,2800$ and $38001 \mathrm{~b}$. respectively. White clover's contribution to seasonal production is. highest in summer, less in spring, still less in autumn, and lowest in winter. The percentage of its annual yield produced in these seasons is, on the average of these four trials, 44, 29, 1'7, and 10 per cent respectively..

The most significant difference in the seasonal growth of the grasses is the relatively high winter production of short-rotation ryegrass. Compared with perennial, its winter production is 56 per cent'higher, although its autumn growth is 40 per cent lower. In the spring the production from the ryegrasses is higher than that from cocksfoot and timothy, and in summer cocksfoot production is the greatest; The highest autumn yield is from perennial ryegrass.

The seasonal production of red clover is indicated by data from a measurement trial sown with Italian ryegrass and broad red. clover in the autumn of 1947. The total production from the spring to the following winter was $95001 \mathrm{~b}$. of dry matter per acre, of which the red clover contributed $36001 \mathrm{~b}$. or 38 per cent. Of the red 'clover yield 70 per cent was produced in the summer and autumn, 46 per cent in the summer, and 24 per cent in the autumn.

With these species there is a sufficient range in seasonal growth to improve the spread of pasture production throughout the year compared with the simple perennial ryegrass-white clover pasture. The addition of short-rotation ryegrass will increase winter and early spring production, and better late summer growth can be obtained from red clover and cocksfoot, particularly on light soils subject to summer droughts.

But, if each species is to make its contribution to production during its particular growing season in a summer pasture, due regard must be paid to its management. 
Adequate establishment of each species must be first obtained 'and thereafter the pasture so managed as to allow particular species to produce to their maximum when required. The ryegrasses establish quickly ; the clovers, cocksfoot, and timothy, slowly. If these, are to become well established, the shading effect of the quickly growing ryegrasses must be reduced. This ' can best be done by frequent fairly close grazing during the early life of the pasture, although relative seeding rates have a strong influence.

Once the pasture is established the relative dominance of each species is determined largely by grazing management. In general, lenient grazing during the period of rapid growth of any plant encourages its dominance. Short-rotation ryegrass is encouraged by lenient grazing in early spring; cocksfoot by such treatment in summer.

Species, too, differ in their reaction to grazing intensity. Perennial ryegrass and white clover will persist under fairly intense continuous defoliation, which would be fatal to short-rotation ryegrass, cocksfoot, and red clover. P. D. Sears has shown at Grass-lands that in only 18 months a pasture of shortrotation ryegrass, perennial ryegrass, cocksfoot, and red and white clover can be reduced to only perennial ryegrass and white clover by continuous hard grazing.

The adaptability of the perennial ryegrass-white clover pasture to grazing management is one of its most valuable features. Under close grazing the ryegrass adopts a prostrate growth habit with fine tillers spreading close to ground level. This growth habit helps to protect the plant against severe defoliation. In similar circumstances white clover also has a smallleaved; prostrate habit of growth, and the combination of the two forms a dense sward. Both can, however, tolerate more lenient grazing, the perennial ryegrass growing more erect and the white clover producing longer petioles and larger leaves.

Relative palatability, too, influences the balance of species in the sward. In a well-established shortrotation ryegrass-cocksfoot pasture preferential grazing of the ryegrass is likely to result in its depression and cocksfoot dominance.

Short-rotation ryegrass is particularly susceptible to hard grazing in late summer. In trials carried out by R. W. Brougham at Grasslands the loss of shortrotation ryegrass from pasture was directly proportional to the severity of grazing during the dry late summer last year. 
The more complex a pasture mixture is the more difficult it becomes to maintain a balance between the constituent species. Different conditions of fertility and grazing bring about a dominance of particular species to the detriment of others, so that, the tendency is for the pasture to develop into one of fewer species favoured by the environmental conditions $\backslash$. Nevertheless, under moderate rotational grazing where defoliation is neither very close nor very lax most species are sufficiently adaptable to. maintain themselves in the sward. Seasonal production can be extended to an appreciable extent by the use of such relatively complex pasture mixtures.

But the periods of shortage can be more adequately provided for by the use of simple mixtures of those species capable of growth in the seasons of low production. In such mixtures, where the interspecific competition is reduced, each is able to grow more strongly during the season to which it is suited. A better distribution of seasonal production on the farm -as a whole is obtained by having some simple special-purpose pastures than by relying solely on more complex general-purpose mixtures.

A combination of short-rotation ryegrass and red clover, together with white clover, is a valuable pasture mixture for both early and late seasonal production. When once established these species will all thrive under fairly lax management, and moreover will retain their good palatability. This mixture is therefore 'well suited to the provision of saved pasture to be rationed during periods of shortage in early spring and late summer, although red clover has its bloat-producing problems. But neither short-rotation ryegrass nor, red clover will stand severe continuous grazing. On the other hand, if either is allowed to become rank during its dominant growth period, the other may be smothered out. Very lax grazing during the early life of the pasture may seriously reduce the content of both red and white clover. Where red clover is dominant, lax grazing during the late summer will likewise affect the short-rotation ryegrass.

Although the present strain of short-rotation ryegrass is inherently more long-lived than previous strains, it may still disappear from a pasture for one reason or another-drought,, overgrazing, or red clover smother in summer. Fortunately, its vigorous seedling growth renders it relatively easily established by oversowing if a few basic principles are observed. 
These principles have been clearly demonstrated in oversowing trials carried out by E. 0. C. Hyde at the Grasslands Division.

Pastures from which short-rotation ryegrass has disappeared are often dominant in clover and therefore not deficient in nitrogen. The stage is therefore set for vigorous grass growth if establishment can be obtained. Mr Hyde's trials have shown that the important principles are :-

1. Early autumn sowing. Autumn is normally preferable to spring sowing,' for during late autumn and winter the grass grows more rapidly than the clover and so can, more readily reach a stage of dominance. Furthermore,. if sowing is delayed until the spring following the disappearance of the grass in the previous summer, the potentially high grass production during winter and early' spring is lost.

2. The dominant clover sward should be closely grazed and surface cultivated before. oversowing.

Fre-cultivation serves two purposes. First, it provides a suitable seed-bed for the grass seed, and second, it reduces the competition from the clover so that the establishing grass seedlings are not overshadowed by a dense canopy of clover.

3 . The first grazing should be delayed until the grass seedlings. have grown well above the clover.

. 'It is in this respect that the management for ryegrass oversowing differs from that for clover oversowing or the establishment of a new pasture. In these latter cases the principle is to graze early to prevent overshading of the slowly establishing clovers. With oversowing ryegrass, on the other hand, the competition from the clover sward has been reduced by the surface cultivation. With the late autumn temperatures more suited to ryegrass than -clover growth, the ryegrass seedlings will grow vigorously psovided they are allowed to make strong growth above the 'clover before being first grazed.

From successful establishment of ryegrass in this way highly producing pastures should be obtained, for with strong clover already' present the pasture should not go through that period of low production in the spring so often associated with new pastures before the clovers have become strongly established.

Under favourable conditions the necessity for oversowing short-rotation ryegrass should not arise. 
But where it has disappeared, and a good clover sward remains, oversowing is sound practice.

I have stressed the value of short-rotation ryegrass used in both general and special-purpose pastures in providing for the early spring shortage. Provision for the late summer is not nearly so readily obtained with pasture species. Although red clover is a good summer producer, it is short lived. Cocksfoot's summer growth is good, but not outstanding. This period can be most reliably catered for by the growing of supplementary crops which provide a feed supply built up during a favourable growing period. The crop also indirectly serves the valuable purpose of being the starting point for pasture renewal.

To summarise: By utilising to the fullest extent the differences in seasonal production inherent in these pedigree strains of grasses and clovers the farmer can materially overcome feed shortages. The pasture is a. dynamic community of plants in which the dominance of individual species is continually changing in response to such environmental factors as season, fertility, and grazing management. The correct use an'd management of. these plants will enable grassland production to be more nearly equated to animal requirements.

\section{DISCUSSION}

Q. What is the quality of the land on which these experiments were carried out? It sounds like the Garden of Eden.

A. It is flat, high-fertility alluvial land at Grasslands Division, Palmerston North, with a well-distributed annual rainfall of 40in.; it is. inclined to be dry in summer. The relative superiority of different strains will be influenced by conditions, such as soil fertility and climate.

Q. Is the land "fat" ?

A. (Hudson): Without white clover the land is capable of producing only at a very low level. Nitrogen and the fertility induced by white clover is the reason for its being "fat".

Q. (Hudson) : In regard to oversowing of short-rotation ryegrass would not drilling into the clover rward be an advantage over broadcasting in that the seed would be actually placed in the soil ?

A. I agree with Prof.. Hudson that the land is "fat" because of the build-up through clover and the grazing animal. In regard to drilling or broadcasting, the important point is to make conditions right for the short-rotation ryegrass to dominate. It is essential to reduce clover competition during the establishment stage of the grass. Pre-cultivaticn does this and also provides a seed-bed. Whether the seed is drilled or broadcast it is important to delay the 
first grazing until the ryegrass seedlings have reached the light and made vigorous growth. With early autumn sowing this may take 7 or 8 weeks, but with late sowing twice as long.

Q. : I suggest there is scope for a dryland ryegrass suitable for Maniatoto. Is it better to have a large number of different strains for different conditions or can one strain carefully selected serve all districts?

A. There is no doubt that regional strains could be produced which would be better for certain districts than the present strains. Trials that have been made at our sub-stations indicate that. But there are many difficulties, in the practical application of such strains. For instance, the ryegrasses are interfertile, and the certification of regional ryegrasses are interfertile, and the certification of regional To produce regional strains it would be necessary to carry out much of the selection and breeding at stations set up in the particular districts and when once produced such strains would have only limited application. There is a good case for additional strains of some of the pasture species, but I consider they should have wide application rather than be particularly suited to only one region. '

Q. If people in Maniatoto tried, rather than Grasslands, and took the present pedigree strain of ryegrass and kept their own seed, wouldthey get a. suitable species for their. own. . conditions ?

A. It is certain you would eventually get a change, but that would not overcome the difficulties that would outbalance the advantages of a regional strain.

Q. Is there any possibility that strains from southern Sweden would be suitable for Maniatoto?

A. The Swedish strains are winter. dormant and tests at Palmerston North showed they are not suitable for that reason. They are too winter dormant even for Maniatoto. 